\title{
Baruga Kare Guesthouse Makassar Financial Reporting System Based on FASS of MSMEs
}

\author{
Yulianus Sampe ${ }^{1}$, Grace T. Pontoh ${ }^{2}$, Robert Jao ${ }^{3}$ \\ \{yulianus.sampe@fe.unhas.ac.id ${ }^{1}$, gracetpontoh@fe.unhas.ac.id², jao_robert@hotmail.com ${ }^{3}$ \} \\ Universitas Hasanuddin, Makassar ${ }^{1,2}$, Universitas Atmajaya ${ }^{3}$
}

\begin{abstract}
The purpose of this study is to analyze the implementation of the Financial Accounting Standard System (FASS) cycle for Micro, Small, and Medium (MSMEs) entities using Wisma Kare Guesthouse as a case. Data were collected using observation and financial reporting document examination. It is found that financial documents were still very limited. The financial report only records cash for a month without proper debit - credit allocation for each transaction. This is a case study in a small guesthouse in the Indonesian cultural context. It needs more verification from other similar enterprises. The practical implication is an accounting report system in small business entities are still need more attention. Social implications of this study are that in order to contribute optimally for economic development, accounting system for small business in accommodation still need to be developed. The paper includes guidelines for implementing the Indonesian Accounting Standard system and relevant.
\end{abstract}

Keywords: Accounting cycles, reporting techniques, guesthouse, SMEs

\section{Introduction}

Accommodation business is a business entity that using a building or part of a building to be used for overnight accommodation, breakfast, lunch, and dinner, and another related service for payment [1]. In the broader scope, accommodation existence supports local economic development, especially for the tourism sector [2]. Accommodation enables tourism to enjoy cheap holidays [3] or comfortable meetings [4]. Accommodation business also may have a positive impact on society for providing supporting business facilities as well as providing employment for the workforce around the establishment.

Guesthouses offer products that comprise tangible and intangible elements that combine into a unique combination of production and service [5]. While room provision is a pure service activity, food, and beverage functions involve processing, and retailing processes are additional services [2], [6]. In order to survive and succeed, a business has to make sure that it is producing the goods or services that the customer wants [3], [7] that it gets its quality right, and that it delivers on time [8]. There is a growing body of evidence that customer satisfaction leads to customer loyalty [2]. So providing accommodation along with excellent service would boost consumer's loyalty.

Each organization has certain objectives, including guesthouse establishment [9]. Management of a guesthouse needs to decide the best allocation of resources to achieve the predetermined objectives [10]. In order to make an optimal decision, financial information is 
needed [11]. In this context, financial information has a close relation to the accounting system [12]. Accounting provides useful information for management to manage the enterprise as well as another stakeholder to evaluate performance and the enterprise condition [13].

Financial information is needed, both external and internal stakeholders [14]. Management is an internal stakeholder that needs financial information in managing enterprise activities [10]. While external stakeholders such as investors, creditors, suppliers, government, and societies also need financial information. Financial information for external stakeholders is called general financial information [11].

\subsection{Guidance to Create Financial Statements Based on Financial Accounting Standard}

Financial Accounting Standards used by an enterprise that doesn't have significant public accountability and provide financial statements for the public (general purpose financial statement) is Financial Accounting Standards for the public financial entity for public accountability [15]. In the MSMEs, however, simple accounting standards are needed due to human resource limitations [9], [14], [16]. FASS for small guesthouse entity needs simple [15]. The FASS is expected to stimulate MSMEs to create a good financial statement and provide reliable financial information.

MSMEs FASS states that financial statements' purpose is to provide a financial position, financial performance, and cash flow for an establishment [12]. The information is useful for management to make an economic decision and for all related stakeholders [15]. Minimal financial statements based on the FASS are end of book financial information, income statement and additional relevant financial records

Baruga Kare Guesthouse's financial transaction records are still very simple. Financial transactions were recorded manually and cash-based using daily cash book. The book only records cash in and cash out. Error in recordings is possible in the manual recording system. Cash in and cash out recapitulation are made at the end of every month to discover cash in hand. The information is used as a basis to estimate if the cash in hand can cover cash need for the coming month, such as to pay salary, electricity bill, and other bills.

The Baruga Kare Guesthouse provides less reliable financial information because it cannot provide detail of the financial transaction. The managerial team doesn't have information about the details of assets. As a consequence, decision making is made without proper financial information.

Currently, Baruga Kare Guesthouse is improving room and new hall facilities. Fund for the improvement is gained from non-banking credit and donations from sponsors and individuals. Unfulfilled standard of financial statements makes the guesthouse is difficult to get funding from a bank.

The study is intended to implement FASS on MSMEs context, the Baruga Kare Guesthouse. The research result is expected to help the business owner to provide bankable financial statements as well as to create financial information based on the FASS in order to make good decision making for all stakeholders. 


\section{Literature Review}

\subsection{Micro, Small and Medium Entities}

Law of the Republic Indonesia Number 20 the Year 2008 regarding Micro, Small, and Medium entities verse 1 states that micro establishment is a productive enterprise owned by individuals and/or sole proprietorship with a total worth of no more than Rp. 50,000,000,(fifty million rupiahs) excluding land and building or annually total sales up to Rp.Rp300,000,000.00 (three hundred million Rupiah). Small enterprise is a productive economic entity owned by an individual or sole proprietorship, not an affiliation or a branch of a large enterprise with a total worth of sales between Rp300,000,000.00 (three hundred million Rupiahs) and 2,500,000,000.00 (two billion five hundred million Rupiah). Medium enterprises are those owned by an individual or sole proprietorship with a net worth between Rp. 500,000,000.- (five hundred million Rupiah) and Rp10,000,000,000.00 ( ten billion rupiahs) excluding building and land or sales between Rp2,500,000,000.00 (two billion five thousand million) and Rp50,000,000,000.00 (fifty billion Rupiah).

\subsection{Accounting Cycle}

The accounting cycle is the accounting process from analyzing and recording transactions and end with closing balance sheet [9], [12]. Warren et al. (2016:176) identify steps in accounting cycles as follow [13].

a. Analyzing and recording transaction into a daily journal

The first step of accounting cycles is analyzing and recording transactions in a journal using debit and credit patterns.

b. Posting the transactions into the ledger

Periodically, the transactions in the journal are posted into the ledger. Debit and credit for each transaction are posted into ledger account based on transaction dates order.

c. Preparing an unadjusted trial balance

Unadjusted trial balance is prepared to determine if there is an error in posting transactions. The unadjusted trial balance only to make sure if the total of the debit side is equal to the total of the credit side.

d. Analyzing adjustment transaction data

Prior to financial report creation, accounts have to be adjusted. There are four accounts that need adjustments, such as prepaid cost, received income (account receivable), and actual expense. In addition, depreciation expense is adjusted, excluding land.

e. Preparing worksheet

Although the worksheet at the end of the accounting period maybe not be so needed, the worksheet is still very useful to provide accounting information path. In addition, the worksheet can be used to analyze the influence of the adjustment on the final financial statement.

f. Journalizing adjusting entries and posting the journal into the ledger.

Each transaction influences at least one profit and loss statement. Explanation of each journal adjustment usually needed.

g. Preparing financial statements 
The most important of accounting cycles is financial statements. The income statement is created first, followed by equity statements and finally financial position. Financial statements can be created from adjusted trial balance or worksheet.

h. Journalizing closing entries and posting to ledger

Four item closing journals are made at the end accounting period in order to prepare the accounts for the next financial period.

The four closing journals are :

i. Debiting all income and crediting income summary.

ii. Crediting all costs and debiting income summary.

iii. Debiting income summary and crediting owner capital.

iv.Crediting withdrawal and debiting capital

i. $\quad$ Preparing a post-closing trial balance

The final steps in preparing a closing balance sheet. The purpose of the balance sheet is to make sure the ledger is ready for the next financial period. All accounts and their balance in the closing balance on the final financial statements are presented in the closing financial statement positions.

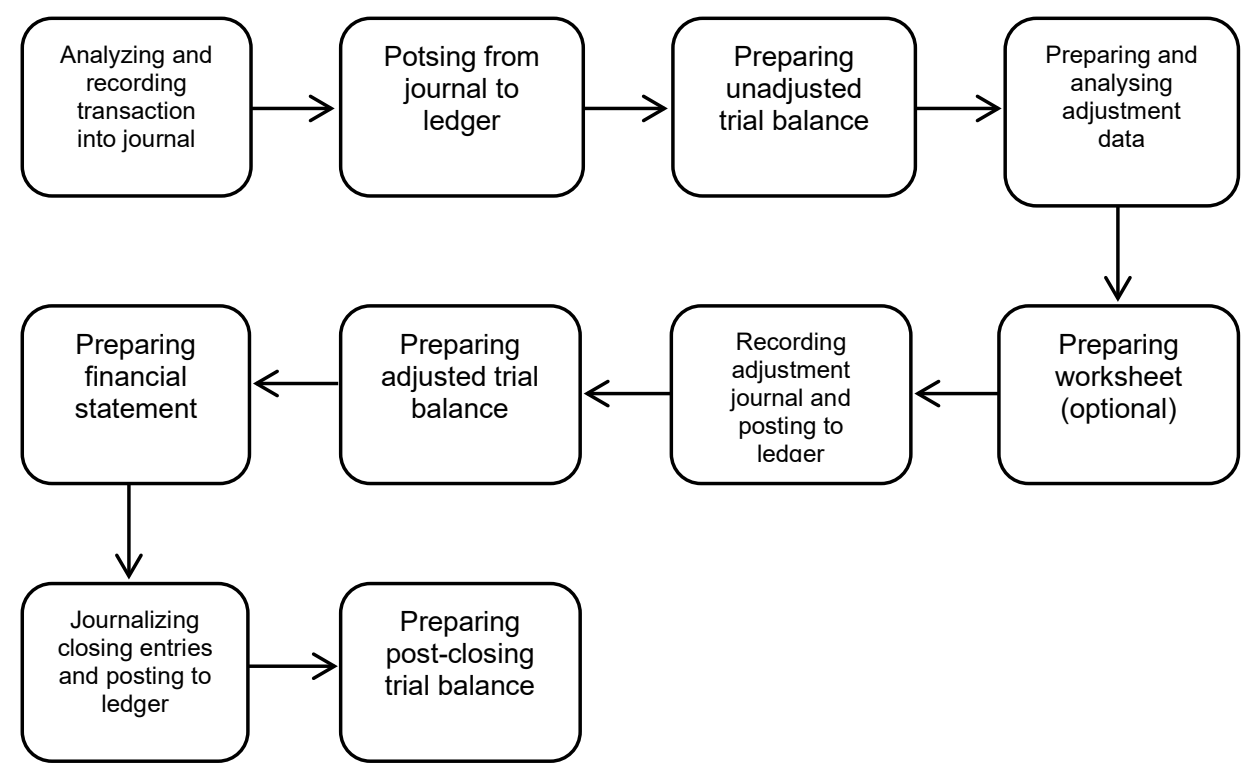

Source: Warren et al. (2016) [13].

Fig. 1. Manual accounting cycle

\subsection{Financial Statements}

Financial statements provide financial information and performance of an entity [14]. The financial statements are useful for economic decision-makers and all relevant stakeholders who don't have privilege access on financial statement. Possible users of the financial statements are resources provider such as creditors and investors. Financial statements show managerial responsibility in resources deployment to produce valauble products. 
Financial statement components are:

a. Assets. Assets are resources owned by a business entity as a result of previous economic transactions, which is expected to earn more economic values during the entity business activities.

b. Liability. Liability is defined as the future sacrifices of economic benefits that the entity is obliged to make to other entities as a result of past transactions or other past events, the settlement of which may result in the transfer or use of assets, provision of services or another yielding of economic benefits in the future.

c. Equity. Often the word equity is used when referring to an ownership interest in a business. Examples include stockholders' equity or owner's equity. Occasionally, equity is used to mean the combination of liabilities and owner's equity. For example, some restate the basic accounting equation Assets $=$ Liabilities + Owner's Equity to become Assets $=$ Equities.

d. Income. Income is the revenue a business earns from selling its goods and services or the money an individual receives in compensation for his or her labor, services, or investments.

e. Expense. An expense in accounting is the money spent or cost incurred in an entity's efforts to generate revenue. Expenses represent the cost of doing business where doing business is the sum total of the activities directed towards making a profit.

Minimum financial statements for micro, small, and medium entities are:

a. Financial statements at the end of the financial period. Financial statements provide information on assets, liability, equity at the end of the financial year. Financial statements include the following accounts:

i.cash and cash equivalent

ii.account receivable

iii.inventories

iv.fixed assets

v.liabilities

vi.bank liabilities

vii.equity

b. Income statements. The income statement shows the financial performance of a business entity for one financial period. The income statement includes:

i.income

ii. financial cost

iii.tax

The firm provides account and details of the account in profit and loss statement if it has relevance to understand financial performance. FASS for MSMEs regulates treatments of financial policy changes as part of income statements during the process of change.

c. Notes of Financial Statements. Notes of a financial statement consist of:

i. a statement that the financial statements are created based on FASS for MSMEs.

ii.accounting policy summary

iii.additional information and details of a certain account to explain important transactions in order to understand the whole financial statements. The additional information depends on business activities done by the entities. Additional financial records are presented as long as it is needed and relevant. 


\section{Research Methods}

The research was conducted at the Baruga Kare Guesthouse in Makassar. The research is applied research due to its purpose to apply accounting theory to solve a problem Subjective data were elaborated using in-depth interview while secondary data were assessed using available documents such as transaction record, daily cash record, cash in the bank, cash in and cash out a record and other relevant documents as well as physical data of inventaris in the guesthouse.

Data collection method steps are:

1. Preparatory survey. The first step included interviews and observation of the business process and book-keeping history during the guesthouse activities as well as investigating available transaction records.

2. Planning step. This step included identification of accounting information needs, accounting policy setting, arranging account list, designing accounting cycles based on the research object condition.

3. Implementation stage. This stage included preparation of prior balance sheet for each account, physical counting, and fixed asset value, and then input all transactions based on accounting cycles.

4. Reporting stage. This stage included financial statement arrangement based on MicroSmall and medium enterprises and other relevant financial statements

\section{Research Results}

\subsection{Preparatory Survey}

Baruga Kare Guesthouse is included in the medium-scale entity. The medium-scale business has a net worth between Rp500,000,000.00 and Rp10,000,000,000.00, excluding land and building and has total sales between $\mathrm{Rp} 2,500,000,000.00$ and $\mathrm{Rp} 10,000,000,000.00$. Baruga Kare Guesthouse provides rooms for overnight accommodation as well as a hallroom for meetings or seminars. It has 64 rooms (48 rooms standards and 16 VIP rooms with three hall rooms. Guests stay overnight for tourism purposes, social service, or other religious activities.

Management applies a very simple book-keeping system. Transaction records are cashbased, only cash in and cash-out transactions are recorded. One employee is responsible for the whole financial transaction of the guesthouse. Financial transactions are recorded based on the transaction invoice and posted in a cash-book once a week. The cash-book provides cash in and cash out records arranged by the transaction date. At the end of the month, the employee makes financial statements. The financial statement shows a cash transaction summary of total income and total expense. Cash expense is used for consumption, salary, transport, inventories, logistic, utility, office inventories, maintenance, and medicines. The financial employee also provides cash on bank statements, including interest and bank administration.

Baruga Kare Guesthouse has not had a financial statement in relation to financial performance(profit or loss) and financial position (assets, liability, and equity). There is no information that relates to fixed assets. Consequently, management cannot manage fixed assets properly. Management also cannot determine the time to add or replace guesthouse assets. 
The monthly transactions are between 150 to 200 transactions from January to June 2017. In detail, between 5 to 15 transactions are cash in the transaction, while about 145 to 195 transactions are cashed out. Low transaction activities, human resource limitation, and business scale are suitable indicators for the Baruga Kare Guesthouse to use FASS for MSMEs.

\subsection{Planning Stage}

Baruga Kare Guesthouse meets criterium as medium enterprises, so FASS for MSMEs can be applied in the entity. Financial statements for MSMEs consist of the balance sheet, income statements, and records on the financial statements. The entity has beds, cupboards, tables, chairs, so detailed records of fixed assets are needed.

In making financial statements, accounting policy is stated as follow :

a. Financial statements use an accrual basis. Transactions are recorded at any time without waiting for cash receipt or payment.

b. Rupiah is used as a currency unit in the financial statement.

c. Monthly accounting period (the financial statement is provided for every month).

d. Account receivable is presented as the value of the bill.

e. Inventories are recorded based on average cost.

f. Fixed assets are recorded as the acquisition cost. Fixed assets are assets with a nominal value of more than Rp500,000.00. Depreciation is counted using the straight-line method without residual.

g. Revenue recognition is accepted when a service is already offered, and the expense is already paid.

Enterprise account list consists of five groups, current assets, noncurrent assets, liability, net-assets, income, and expense. Account code is numeric that consists of five number and presented as follows:

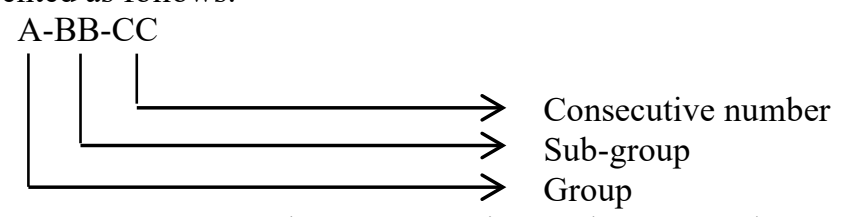

Baruga Kare Guesthouse accounting cycles are not done manually but are done by using Microsoft Excel software. The usage of this software enables us to make financial statements easily. Financial cycles of the entity are presented in the following figure:

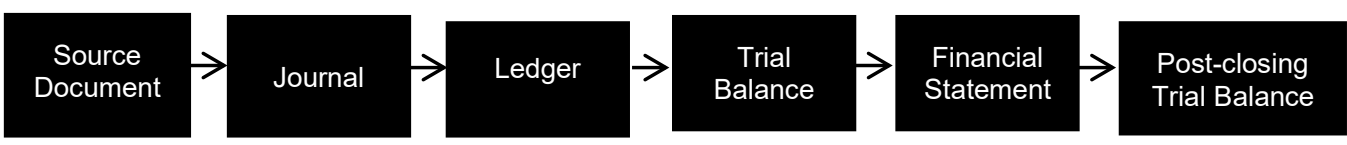

Fig. 2. Baruga Kare Guesthouse Accounting Cycles

Accounting cycle creation is simpler because of Microsoft Excel software usage. Transaction invoice $\mathrm{s}$ are recorded at the end of a month. The adjustment process is also recorded on the trial balance sheet at the end of the month. The software also provides an automatic entries process into the ledger. After the entries process, the balance sheet will be automatically updated. Balance sheet data in the form of assets, liabilities, dan equity will be 
posted into the balance sheet while income and expense will be posted into the income statement.

\subsection{Implementation Stage}

Completing the initial survey and planning, the next step is implementing the accounting cycles. Baruga Kare Guesthouse is already well-established. However, financial activities only are recorded in a cash-book. Management has to make a cut-off point to determine initial balance from assets, liabilities, and equity. The initial balance will be the basis for the transaction of the coming financial period. The cut-off point is decided to be the $1^{\text {st }}$ of January 2017.

The initial balance is:

a. Cash-in-hand. Cash balance for cash-in-hand is set to base on cash-book actual balance.

b. Cash-in-bank. Cash-in-bank balance is based on saving account balance.

c. Account receivable. Account receivable balance is determined based on debtor invoices.

d. Inventories. Inventory balance is determined based on physical stock-checking and inventories buying invoices.

e. Equipment. Equipment balance is determined based on physical stock-checking and equipment buying invoices.

f. Fixed Asset. A fixed asset balance is determined based on a physical observation record. Fixed asset depreciation is applied from January $1^{\text {st }}, 2017$.

g. Account payable. Account payable balance is determined based on creditors' invoices.

h. Equity. Equity is determined based on the difference between total assets and total liabilities. In case of debt is equal to zero, the equity is equal to total assets.

Baruga Kare Guesthouse has a great number of fixed assets, so physical count consumes much time. Physical counting and acquisition cost of the fixed assets were conducted folowing the next steps:

a. Coding and numbering fixed asset using the following form :

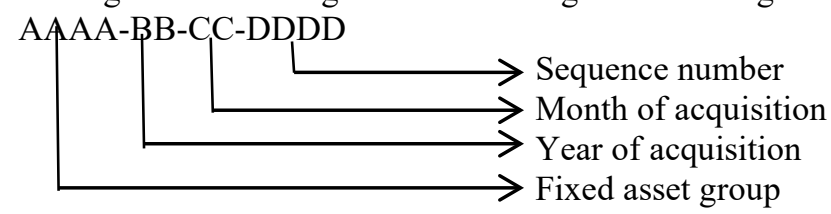

Where :

1210 : Land

1220 : Building

1230 : Vehicle

1240 : Machine

1250 : Guesthouse equipment

1260 : General equipment

b. Identification of fixed assets by giving identity number, name, and location of a fixed asset. 


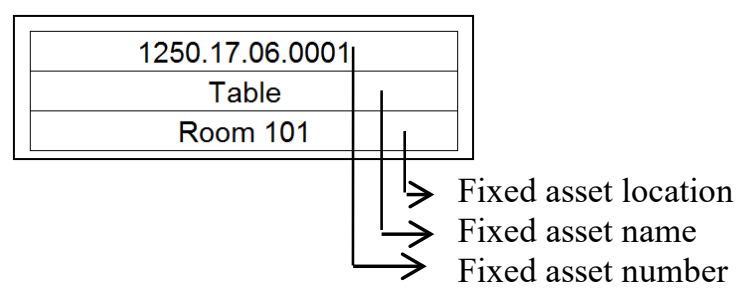

Fig. 3. Example of Fixed Asset Identit

c. The numbered fixed asset then recorded on fixed assets form physical-checking. The form is presented in figure 4 below.

LOCATION :

\begin{tabular}{|c|c|l|l|l||}
\hline No. & Code & Item & Brand & Explanation \\
\hline \hline 1 & & & & \\
\hline 2 & & & & \\
\hline 3 & & & & \\
\hline 4 & & & & \\
\hline 5 & & & & \\
\hline
\end{tabular}

Fig. 4. Form of Physical Checking of Fixed Assets

d. Acquisition price determination is based on the normal price. The decision is made because a fixed asset has been owned for a long period of time while no transaction invoice.

e. Based on physical form examination, a form of each fixed asset is made for each group by writing code, name, merk, acquisition price, depreciation, depreciation accumulation, and fixed value of the asset.

After determining the initial balance, the next step is to enter the financial data for January 2017 up to June on the journal column.

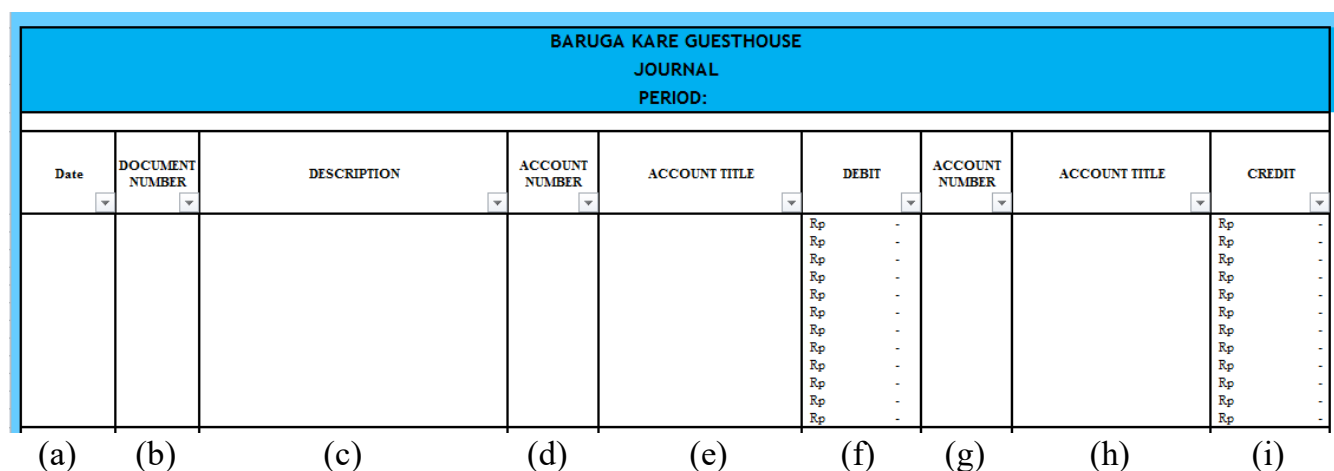

(a) (b)

(c)

(d)

(e)

(f)

(g)

(h)

(i)

Where

Fig. 5. Journal Form of Baruga Kare Guesthouse
a. Transaction date
b. Transaction proof number
c. Transaction description
d. The account number on the debit side 


$$
\begin{array}{ll}
\text { e. } & \text { Account name on debit side (automatic) } \\
\text { f. Rupiah amount on the debit side } \\
\text { g. The account number on the credit side } \\
\text { h. Account name on the credit side (automatic) } \\
\text { i. Rupiah amount on the credit side (automatic) }
\end{array}
$$

Journal entries are the first step. Transaction entries are done chronologically based dates sequence. Careful entries are needed. Transactional analysis has to be made accurately to determine the debit and credit of a transaction. Book entries to ledger, trial balance sheet, financial statement, and post-closing trial balance are created by the software. If an error occurs, the next step also will error.

\subsection{Reporting Stage}

The statement of financial position can be presented in detail as well as the income statement. Details of financial statements show the balance of each account, while financial statements only presented in summary form. The statement of financial position is presented in figure 6, while the income statement is presented in figure 7.

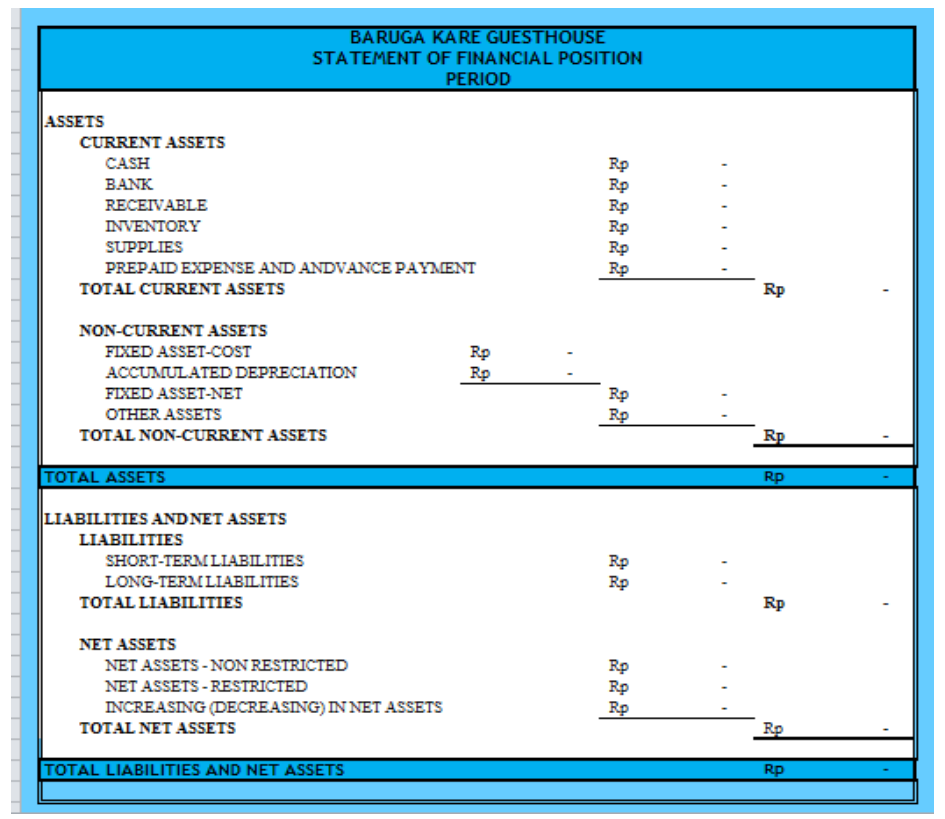

Fig. 6. Statement of Financial Position Form of the Baruga Kare Guesthouse 


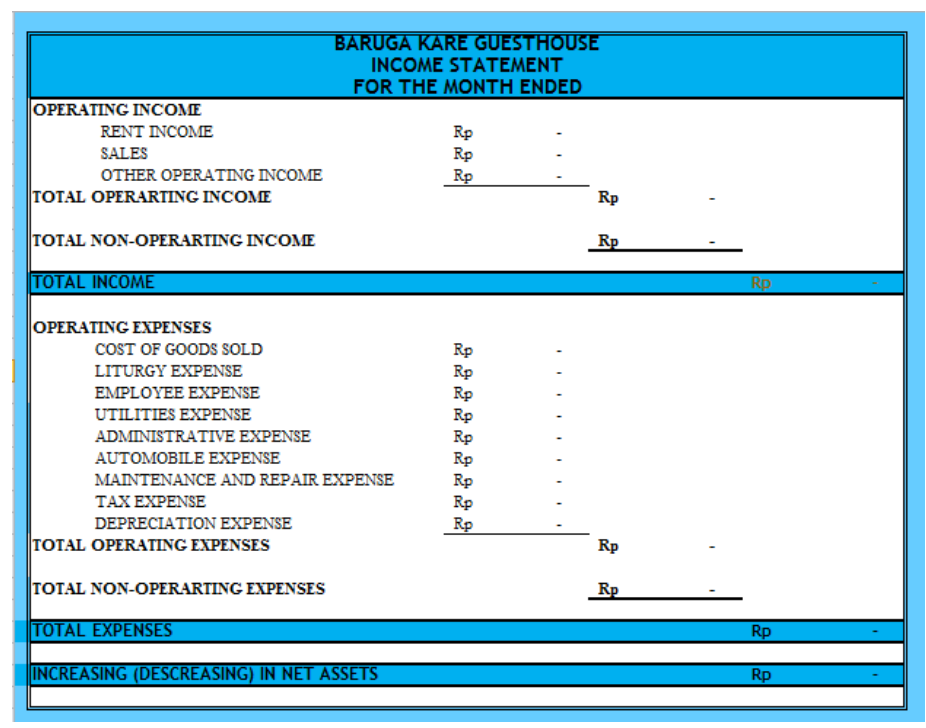

Fig. 7. Income Statement Form of the Baruga Kare Guesthouse

Statement of Financial Position consists of current assets, fixed assets, short-term liabilities, long-term liabilities, and equity (net asset), while income statement consists of operating income, operating expense, other income, and other expenses.

\section{Conclusion and Sugestion}

Baruga Kare Guesthouse makes a simple financial transaction record. A recording is made manually using daily cash-book. At the end of a month, the financial staff recapitulates cash-in and cash-out to discover cash balance. The financial information provided is still not enough because the management team and relate stakeholders only find limited information about the financial condition. To meet enough accounting information, Baruga Kare Guesthouse should apply Micro, Small, and Medium Enterprises (MSMEs) Financial Accounting Standard (FAS) as the basis of making financial statements. The standard is a simpler standard and regulates general transactions for MSMEs.

In order to generate accounting information, a set of steps are needed. The steps are presurvey to make sure if an enterprise meets criteria as MSMEs and suitable to use FAS. They were then followed by planning steps to set accounting policy, account list preparation, and accounting cycle design. The next step is the development of FAS, including recording transactions into the journal, reporting stage that presenting statements of financial position, income statement, and notes to the financial statement.

It is suggested that Baruga Kare Guesthouse provide financial statements based on FAS for MSMEs on a predetermined time. The financial statements are expected to provide reliable financial information for all related stakeholders to make the best decision either to develop the entity or to evaluate financial performance. Human resource skills and expertise in accounting need to be developed in order to enable the FAS application in the Baruga Kare Guesthouse. 


\section{References}

[1] BPS.: Konsep dan Definisi Statistik Hotel dan Akomodasi Lainnya di Indonesia (2017).

[2] Amoah. F, Radder L, and van Eyk M.: Perceived experience value, satisfaction and behavioural intentions. African Journal of Economic and Management Studies. vol. 7, no. 3, pp. 419-433 (2016).

[3] Mohajerani. P and Miremadi. A.: Customer satisfaction modeling in hotel industry: A case study of Kish Island in Iran. International Journal of Marketing Studies. vol. 4, no. 3, pp. 1-19 (2012).

[4] Morrison. A and Teixeira .R.: Small business performance: a tourism sector focus. Journal of Small Business and Enterprise Development. vol. 11, no. 2, pp. 166-173 (2004).

[5] Ingram. H.: Classification and grading of smaller hotels, guesthouses and bed and breakfast accommodation. International Journal of Contemporary Hospitality Management.vol. 8, no. 5, pp. 30-34 (1996).

[6] Frochot.I and Batat. W.: Marketing and designing the tourist experience. Goodfellow Oxford (2013).

[7] Oh, A. M. Fiore. H, and Jeoung. M.: Measuring experience economy concepts: Tourism applications. Journal of travel research. vol. 46, no. 2, pp. 119-132 (2007).

[8] Hosany. S and Witham.M.: Dimensions of cruisers' experiences, satisfaction, and intention to recommend. Journal of Travel Research. vol. 49, no. 3, pp. 351-364 (2010).

[9] Dang-Duc. S.: Compliance with accounting standards by SMEs in transitional economies: evidence from Vietnam,. Journal of Applied Accounting Research. vol. 12, no. 2, pp. 96-107 (2011).

[10] Kissi. M and Owusu-Mintah S.B.: Quality assurance in ghanaian hotels and restaurants. African Journal of Applied Research (AJAR). vol. 2, no. 2, pp. 72-82 (2015).

[11] Suwardjono.: Akuntansi Pengantar: Proses Penciptaan Data Pendekatan Sistem, 3rd ed. BPFEYogyakarta: Yogyakarta (2014).

[12] Boolaky. P.K.: Accounting development and international financial reporting standards in small island economies. Journal of Accounting in Emerging Economies. vol. 2, no. 1, pp. 4-29 (2012).

[13] Warren. C.S. et al.: Pengantar Akuntansi: Adaptasi Indonesia. Salemba Empat :Jakarta (2016)

[14] M. Kiliç, A. Uyar, and B. Ataman.: Preparedness of the entities for the IFRS for SMEs: An emerging country case. Journal of Accounting in Emerging Economie. vol. 6, no. 2, pp. 156-178 (2016).

[15] Ikatan Akuntan Indonesia.: Standar Akuntansi Keuangan Entitas Tanpa Akuntanbilitas Publik (SAK ETAP). DSAK-IAI: Jakarta (2016).

[16] Stainbank. L.J.: An examination of the due process in South Africa which led to the adoption of the draft International Financial Reporting Standard for Small and Medium-sized Entities. Meditari: Research Journal of the School of Accounting Sciences. vol. 18, no. 2, pp. 57-71 (2010). 